\title{
Ethnobotanical Study of Medicinal Plants Used in the Province of Sidi Slimane (Morocco)
}

\author{
A. Zaher ${ }^{1 *}$, M. Boufellous ${ }^{2}$, H. Jaber ${ }^{1}$, H. El Hartiti ${ }^{1}$, M. Barrahi' ${ }^{1}$, M. Ouhssine ${ }^{1}$, B. Bourkhiss ${ }^{1}$ \\ ${ }^{1}$ Laboratory of Agro-Physiology, Biotechnologies, Environment and Quality, Department of Biology, Faculty of Sciences, \\ University Ibn Tofail, Kénitra, Maroc \\ ${ }^{2}$ Laboratory of Biochemistry, Biotechnologies, Environment and Health, Department of Biology, Faculty of Sciences, \\ University Ibn Tofail, Kénitra, Maroc \\ Email: ${ }^{\star}$ zaher.aouatife@gmail.com
}

How to cite this paper: Zaher, A., Boufellous, M., Jaber, H., El Hartiti, H., Barrahi, M., Ouhssine, M. and Bourkhiss, B. (2018) Ethnobotanical Study of Medicinal Plants Used in the Province of Sidi Slimane (Morocco). Journal of Biosciences and Medicines, 6, 25-35.

https://doi.org/10.4236/jbm.2018.69003

Received: August 1, 2018

Accepted: September 9, 2018

Published: September 12, 2018

Copyright $\odot 2018$ by authors and Scientific Research Publishing Inc. This work is licensed under the Creative Commons Attribution International License (CC BY 4.0).

http://creativecommons.org/licenses/by/4.0/

\begin{abstract}
An ethnobotanical study of medicinal plants carried out in the province of Sidi Slimane (Rabat-Salé-Kénitra Region). It has been added to the catalog of medicinal plants and to classify all the information concerning the therapeutic uses practiced by the local population. Using 300 questionnaire cards, ethnobotanical surveys were conducted over a period of two years (2015 and 2016). The survey allowed us to identify 46 species belonging to 43 genera and 24 botanical families. In addition, the leaves are the most used part as an infusion to treat diseases. In terms of diseases treated, digestive disorders rank first (31.59\%), followed by respiratory diseases $(24.30 \%)$ and diseases of the nervous system (17.01\%). The results obtained will be a very valuable source of information for the region studied and for the scientific community. They could be a database for further research in the fields of phytochemistry and pharmacology and for the purpose of searching for new natural substances.
\end{abstract}

\section{Keywords}

Ethnobotanical Study, Province of Sidi Slimane, Medicinal Plants, Floristic

\section{Introduction}

The use of aromatic plants by human is an ancient practice [1]. Nowadays, the majority of the inhabitants of the terrestrial world use very many plants, considering their aromatic properties, as a source of seasoning or as a remedy in traditional medicine. However, this use is not based on any scientific criterion; it simply takes into account observations over the centuries [2]. The plant species 
of medicinal interest are involved in different sectors in the raw state or in the form of oils, extracts, aqueous or organic solutions [3]. Their plant-based preparations contain one or more active ingredients useful for therapeutic purposes [4].

Morocco, with its geographical contrasts, offers a varied range of bioclimates allowing the installation of a rich flora (more than 4200 species) and a diversity of phylogenetic resources in MAP (600 species) [5]. In addition to this promising natural context, Morocco's WFP-related activity is rich and diversified, which is an important asset for the establishment and development of the sector. The province of Sidi Slimane is rich with this type of plants that are widely used in traditional medicine.

Our study aims to complete our knowledge on the use of medicinal plants used by the population of the province of Sidi Slimane (northwestern Morocco). In this context, surveys were conducted among the inhabitants of this region in order to gather as much information as possible about the use of these medicinal plants.

\section{Material and Methods}

\subsection{Description of the Study Area}

Located in the northwest of the country, the province of Sidi Slimane is one of the newly created Moroccan provinces (2009), belonging to the region of Rabat-Salé-Kenitra. This province contains 320,407 inhabitants (2014), the rural areas have 189,439 inhabitants or $59.12 \%$ and the urban area 130,968 inhabitants, that is, $40.88 \%$. The province of Sidi Slimane (Figure 1) is $100 \mathrm{~km}$ from the capital Rabat, it covers an area of $1492 \mathrm{~km}^{2}, 34^{\circ} 15^{\prime} 53^{\prime \prime}$ North latitude, $5^{\circ} 55^{\prime} 33^{\prime \prime}$ West and an altitude compared to the sea level: $37 \mathrm{~m}$.

It is bounded on the north by the provinces of Sidi Kacem and Kenitra, on the south by the provinces of Meknes and Khmisset, on the east by the provinces of Fez and Sidi Kacem and on the west by the province of Kenitra [6].

Sidi Slimane has a warm Mediterranean climate with dry summer (Csa) according to the classification of Koppen-Geiger. The average annual temperature for the year is $17.3^{\circ} \mathrm{C}$ and the average rainfall is $527.9 \mathrm{~mm}$. The summers are much rainier than the winters. The variation in precipitation between the driest month and the wettest month is $85 \mathrm{~mm}$. The variation in temperatures throughout the year is $15.3^{\circ} \mathrm{C}$. With an average of $26.9^{\circ} \mathrm{C}$, August is the warmest month. With an average of $11.6^{\circ} \mathrm{C}$, January is the coldest month. The precipitation varies $85 \mathrm{~mm}$ between the driest month and the wettest month. The variation in temperatures throughout the year is $15.3^{\circ} \mathrm{C}$.

\subsection{Methodological Approach}

Using 300 questionnaire cards, ethnobotanical field surveys were conducted during two 2015 and 2016 campaigns. The studied territory is divided into 6 zones corresponding to the number of caildats attached to the province of Sidi 


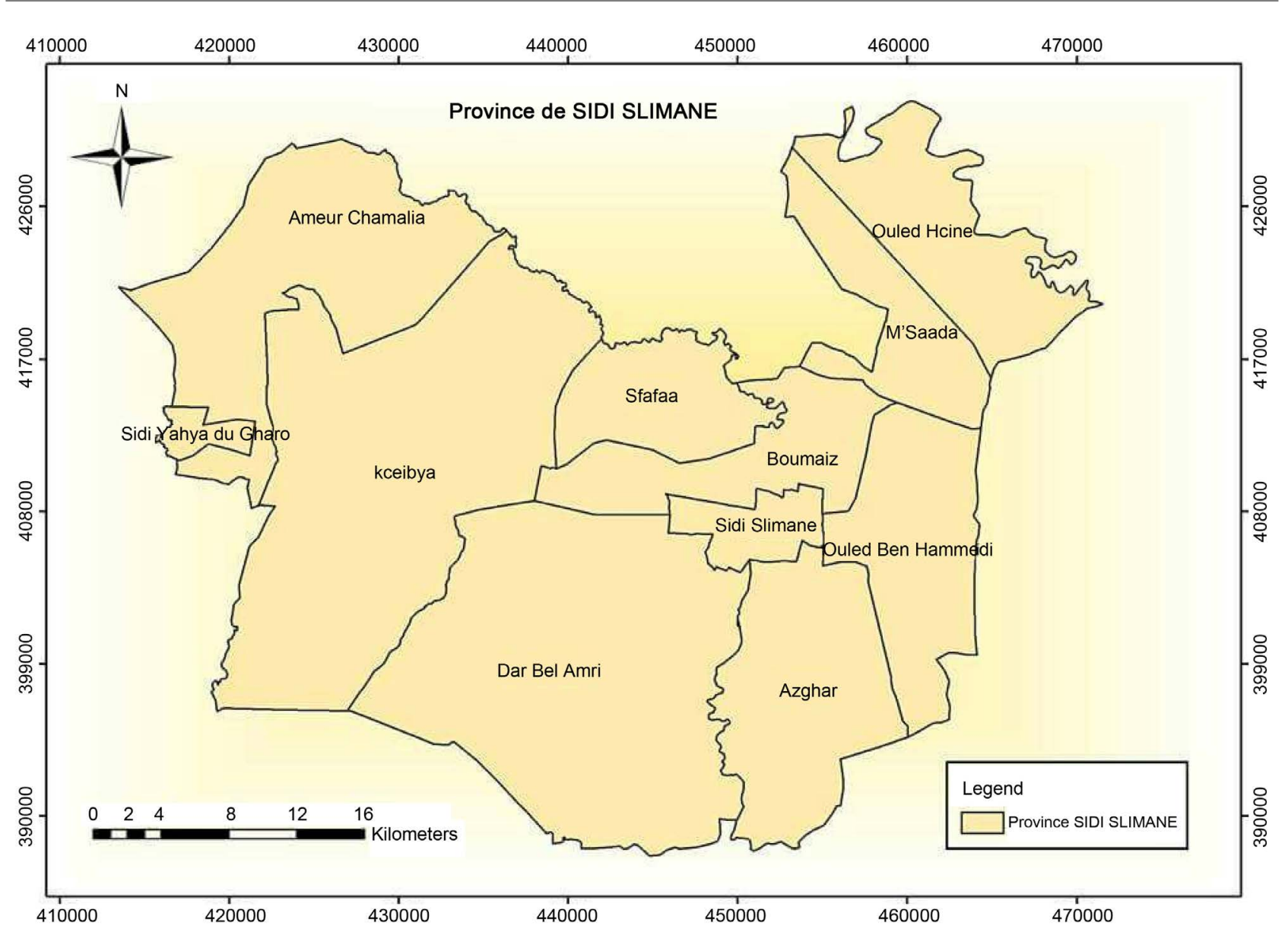

Figure 1. Distribution of survey points across the province of Sidi Slimane.

Slimane.

The ethnobotanical study was conducted following a series of surveys conducted using a pre-established questionnaire with specific questions about the informant (age, level of education, etc.). Two medicines (modern and traditional), the common local name of the plant, the part (s) used, the method of preparation and the type of diseases treated.

The determination of the scientific nomenclature was carried out for each species, thanks to the following documents:

- Practical flora of Morocco of Fennane et al. (1999) [7];

- Vascular flora of Morocco: inventory and chorology of Fennane and Ibn Tatt or (2005) [8];

- The traditional Moroccan pharmacopoeia of Bellakhder (1997) [9].

\subsection{Sampling}

According to the list of circles, caids and communes of 2009, the province of Sidi Slimane is composed of 11 municipalities, including two urban municipalities (or municipalities): Sidi Slimane and Sidi Yahya El Gharb.

The remaining 9 rural communes are attached to 5 caidats (themselves attached to the circle of Sidi Slimane): 
- Boumaiz Caidat: Oulad Ben Hammadi and Boumaiz;

- Keceibya Caidat: Sfafaa and Kceibya;

- Caidate of Dar Bel Amri: Azghar and Dar Bel Amri;

- Caidat of M'saada: M’Saada and Oulad H'Cine;

- Caesat of Ameur Chamalia: Ameur Chamalia.

Since none of these rural communes have a center approved as an urban center, the only localities considered as cities are these municipalities: Sidi Slimane and Sidi Yahya El Gharb.

For a better representation of the region, we proceeded to a proportional stratified random sampling [10] (Table 1).

The data entered on the raw data sheets were transferred to a database and processed by the SPSS (System Package for Social Sciences, version 11.5) statistical processing software.

\section{Results and Discussion}

The results obtained are listed according to the therapeutic practices, the use of the plants as well as the treatment of the diseases. All listed species are presented in the form of a catalog (Annex Table A1).

\subsection{Frequency of Use of Medicinal Plants according to the Profile of the Respondents Sex of Belonging}

The ethnobotanical survey fact sheet was filled out with 300 people, including 206 female (68\%), and 94 male (31\%) (Figure 2(a)).

\subsection{Age Range}

The age range of informants, whose intellectual levels are different, varies between 17 and 30 years, the predominance of which tends to those aged 31 to 50 (54\%). However, for the age group 17 to 30 years, we noted a rate of recourse to medicinal plants of $38 \%$. For older people, the use of medicinal plants at home is not of great therapeutic interest (8\%) (Figure 2(b)).

\subsection{Family Situation}

The majority of users of medicinal plants are married (72.66\%), while the single

Table 1. Distribution of respondents by each stratum.

\begin{tabular}{ccc}
\hline Strata & Names of strata & Number of investigations \\
\hline Stratum 1 & Sidi Slimane-Sidi Yahya & 50 \\
Stratum 2 & Oulad Ben Hammadi et Boumaiz & 50 \\
Stratum 3 & Sfafaa et Kceibya & 50 \\
Stratum 4 & Azghar et Dar Bel Amri & 50 \\
Stratum 5 & M'Saada et Oulad H'Cine & 50 \\
Stratum 6 & Ameur Chamalia & 50 \\
& Sample & 300 \\
\hline
\end{tabular}




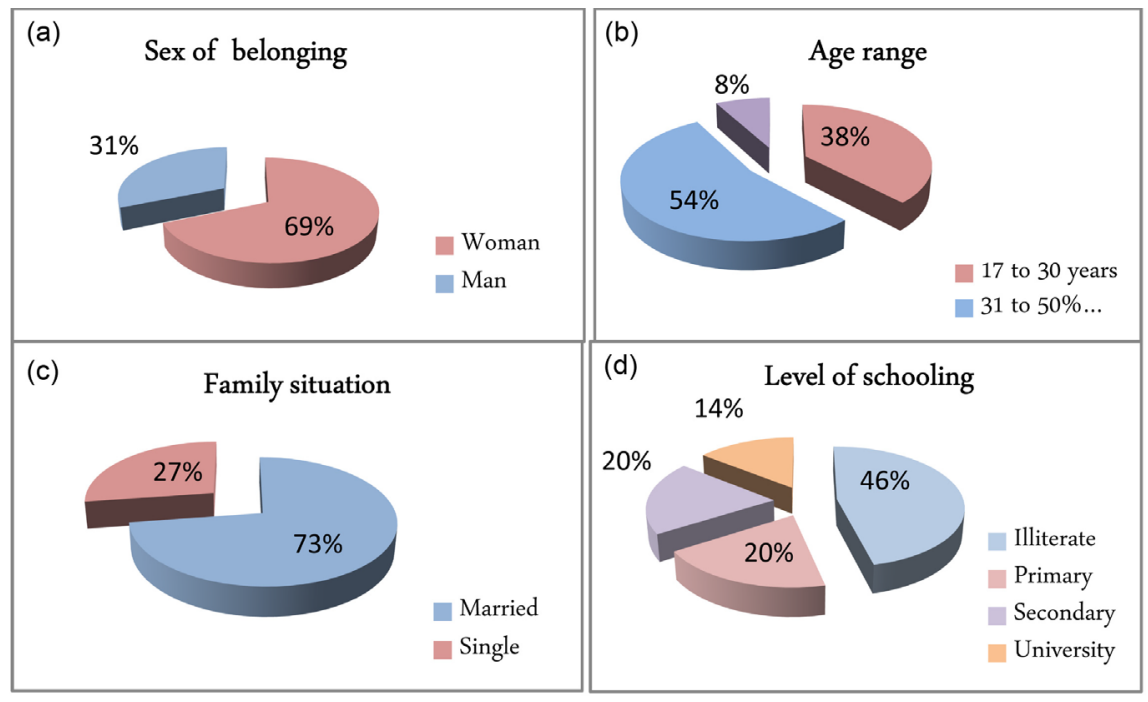

Figure 2. Distribution of users of medicinal plants by occupation (a), age (b), family status (c) and level of schooling (d).

users are $27.33 \%$, this is probably due to the desire to reduce the costs of medical visits and pharmacy (Figure 2(c)).

\subsection{Level of Schooling}

The vast majority of users of medicinal plants are illiterate with a percentage of $46.33 \%$. However, those with a level of primary and secondary education have a recourse percentage of $19.66 \%$, while those with a university level use medicinal plants with a smaller percentage (14.33\%) (Figure 2(d)).

The clearly high illiteracy rate in the region may be an obstacle to the use of medicinal plants and may even be a real obstacle to local economic development and may contribute to the degradation of natural resources.

\subsection{Choice between Traditional Medicine and Modern Medicine}

The survey conducted in the province of Sidi Slimane, allowed us to divide the population into 3 classes (Figure 3). Regarding therapeutic practices, 116 people (38.66\%) of the population use both traditional and modern medicine. However, $29.33 \%$ of users prefer modern medicine and $32 \%$ use traditional medicine alone.

\subsection{Origin of Information Concerning the Use of Medicinal Plants}

$50.33 \%$ of the population refers to the experiences of others, which confirms the transmission of traditional practices from one generation to the next. At the same time, $27.33 \%$ of users refer to themselves and $22.33 \%$ refer to herbalists.

\subsection{Medicinal Species Used in the Study Area}

\subsubsection{Medicinal Plants with Very Frequent Use}

At the end of the survey, 46 species are identified. These medicinal species belong 


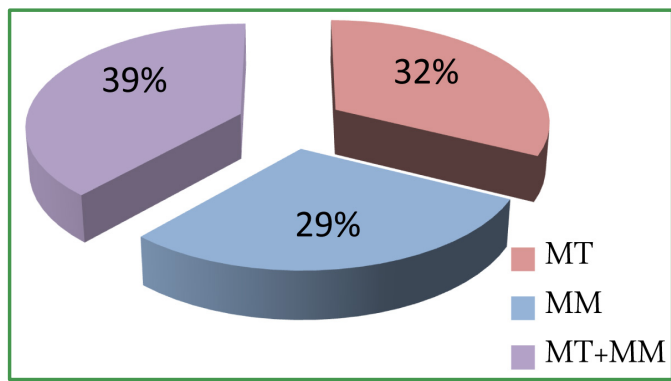

Figure 3. Use of medicinal plants according to therapeutic practice (TM: Traditional Medicine/MM: Modern Medicine).

to 43 genera and 24 botanical families.

Among the 24 families identified in the region, the most represented families are Lamiaceae (11 species or $23.91 \%$ ), Apiaceae (7 species or $15.21 \%$ ), Asteraceae (3 species or 6.52\%), Fabaceae, Myrtaceae, Liliaceae and Zygophyllaceae with 2 species each (4.34\%). These families alone hold 29 species (63.04\%), the remaining families have only one species (17 species or 36.95\%) of the global population. This result is consistent with that obtained by Mehdioui and Kahouadji (2007) and Hseini et al. (2007) [11] [12].

The analysis of the information collected shows that among the 45 medicinal species reported in the province of Sidi Slimane (Annex Table A1), only 10 plants are the most used (Figure 4). The Origanum vulgare species was reported by 160 individuals, followed by Mentha piperita (100), Chenopodium ambrosioides L. (90), Mentha pulegium L. and Vervena officinalis (70), Marrubium vulgare and Salvia officinalis (50), Lavandula officinalis (40), Romarinus officinalis and Ammi visnaga L. Lam. (30), while other plants are poorly reported by the local population.

\subsubsection{Used Parts}

In the study area, the leaves are the most used parts in the treatment of diseases mentioned with a percentage of $69.79 \%$ (Figure 5). Then come the leafy stems and the flowers with $34.37 \%, 34.02 \%$ of use respectively. Seeds and aerial parts are used with a percentage of $26.73 \%, 26.04 \%$ respectively. However rhizomes occupy an average place with a percentage of $21.52 \%$ while the roots present a percentage of $12.15 \%$. The rest (stems, bulb, and fruit) makes use of the population with a small percentage ( $6 \%$ to $2 \%$ ).

It appears that the parts used are the leaves and stems. Also, the use of leaves can be explained by the ease and speed of their harvest [13] and by the fact that they are the seat of photosynthesis and sometimes the storage of secondary metabolites, responsible for biological properties of the plant.

\subsubsection{Method of Preparation}

Different therapeutic practices are used by the local population for treatment. The most applied mode in the province of Sidi Slimane is the infusion (31.59\%) 


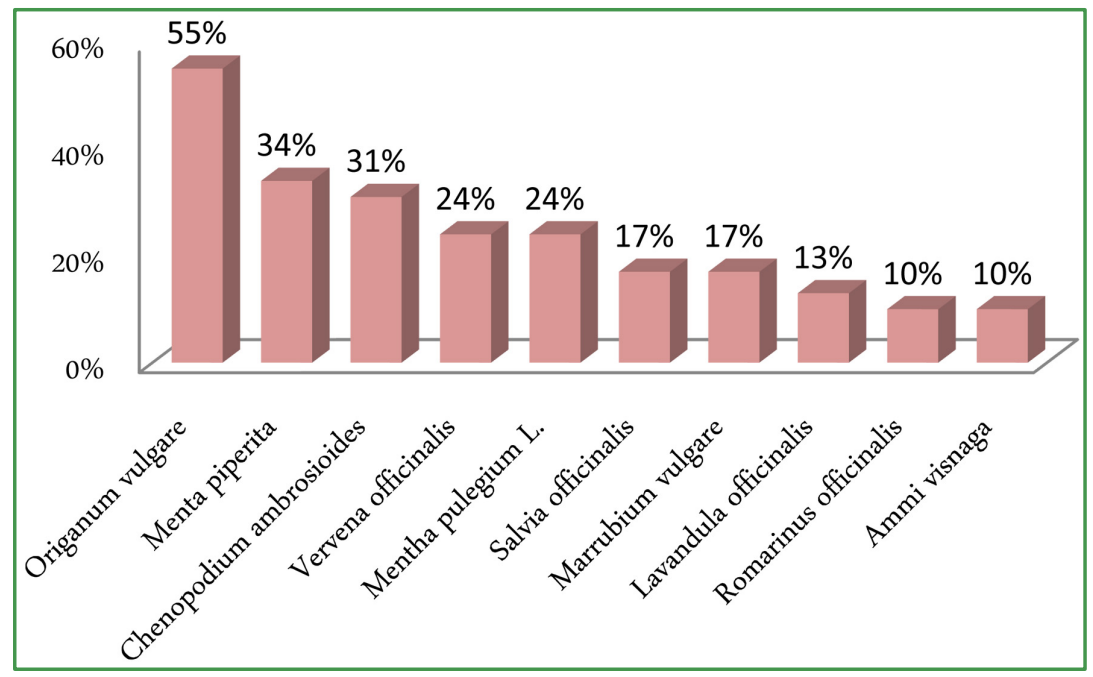

Figure 4. Medicinal plants most used in the study area.

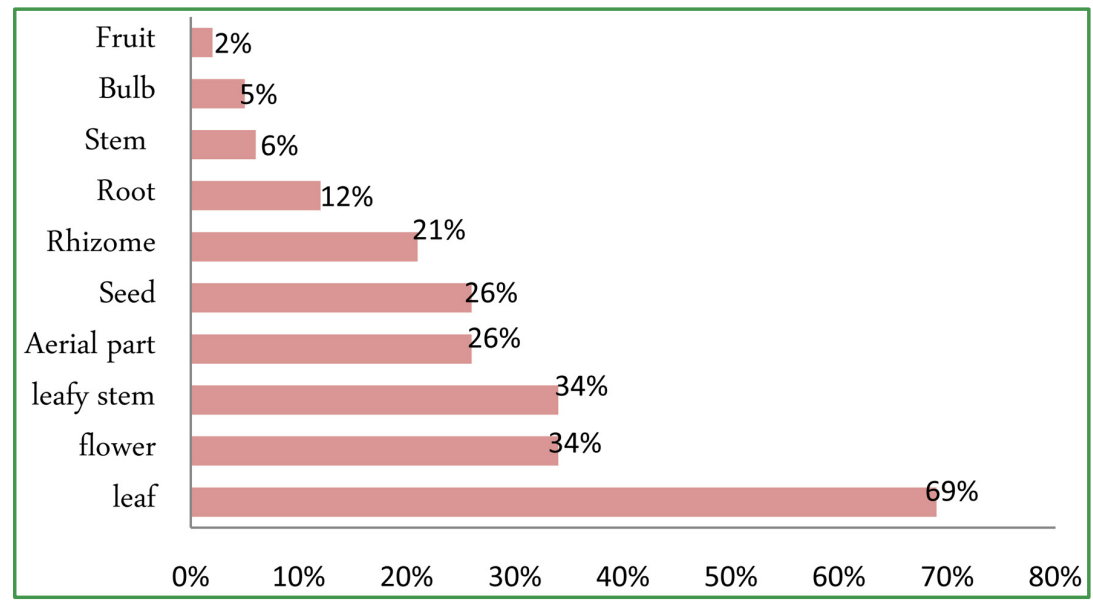

Figure 5. Distribution of percentages of different parts used medicinal plants.

followed by the raw $(21.87 \%)$, cooked $(17.70 \%)$, poultice $(14.58 \%)$, powder (9.72\%), decoction (9.02\%), maceration and fumigation (4.86\%) (Figure 6).

\subsubsection{Herbal Medicine and Treated Diseases}

The ethnobotanical survey revealed that the majority of medicinal species are used primarily against diseases of the digestive system, with a percentage of $31.59 \%$ (Figure 7). Diseases of the respiratory system come second with $24.30 \%$. The diseases of the nervous system are in third position with $17.01 \%$. Dermal diseases are at $14 \%$ presence. Uro-genital diseases and those of the metabolic system are at $4 \%$. The rest of the diseases (visual and osteoarticular apparatus) is represented by only $2 \%$.

\subsubsection{Results of Care}

$43.75 \%$ of the study population thinks that medicinal plants allow a cure of diseases, while $41.31 \%$ consider that the use of medicinal plants only allows an improvement of the state of health, nevertheless $10.76 \%$ of local people believe 


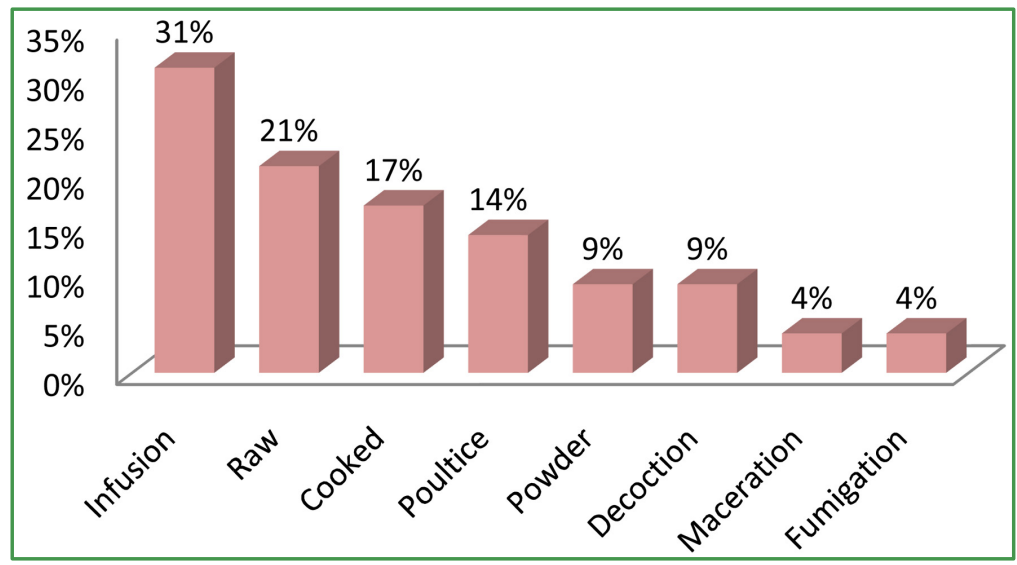

Figure 6. Distribution of different modes of preparations of medicinal plants.

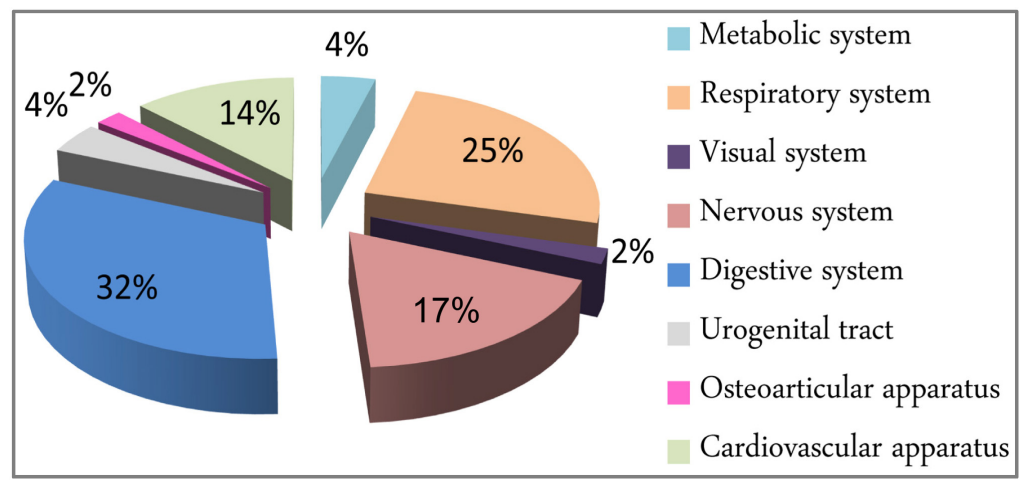

Figure 7. Distribution of different uses of medicinal plants in the province of Sidi Slimane.

that medicinal plants cause side effects, while $4.16 \%$ believe that herbal remedies cause side effects (Figure 8).

\subsubsection{Toxic Plants}

The present study also showed that only $35.06 \%$ of the population knows the toxic plants, against $64.93 \%$ of those questioned ignore the toxicity of medicinal plants. The most cited are Nerium oleander, Cnicus benedictus, Berberis, Ricinus communis L., Peganum harmala and Citrullus colocynthis.

\section{Conclusions}

Despite the development of the chemical medicine industry, traditional herbal medicine is currently a cure-all. The present study made it possible to carry out an inventory as complete as possible of the medicinal plants used in the province of Sidi Slimane (Rabat-Salé-Kénitra region) and to collect information concerning the therapeutic uses practiced in this region. The ethnobotanical survey revealed a multitude of results. About 46 medicinal plant species are reported, divided into 24 families of which the most used species is Origanum vulgare, and the most represented family is that of Lamiaceae. The people surveyed are mostly aged between 31 and 50, illiterate, married and without a profession. Also, 


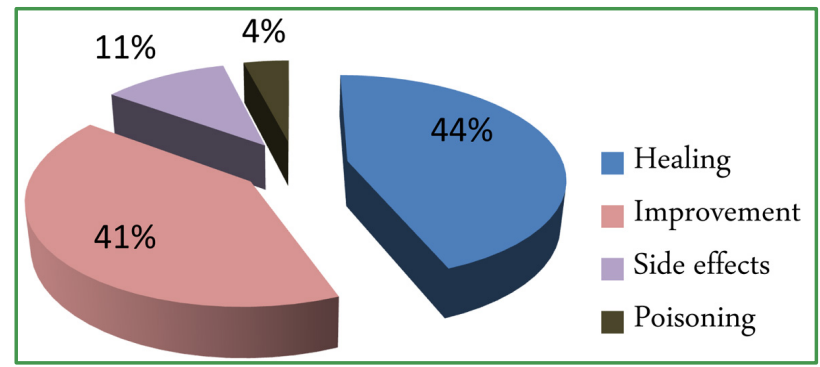

Figure 8. Distribution of care outcomes.

medicinal plants attract much more attention from women who know their value and therapeutic effects better than men. Thus, the leaves are the most used part and most of the recipes are prepared mainly with unspecified doses in the form of infusion. Thus, the distribution of frequency of use of medicinal plants according to the group of the treated diseases shows that the digestive affections are the major therapeutic indications. Similarly, the collection and analysis of the collected data made it possible to transform oral folk knowledge in this region into transcribed knowledge through the establishment of a catalog of the medicinal plants used and their therapeutic use.

Despite the encouraging results of this survey concerning phytotherapy, its practice in the province of Sidi Slimane remains limited. Medicinal plants, like medicines, must have strict standard rules that only the specialist in herbal medicine can meet. Thus, it is necessary to give more importance to the cultivation, exploitation and marketing of these plants which can be an important source of external income.

\section{Conflicts of Interest}

The authors declare no conflicts of interest regarding the publication of this paper.

\section{References}

[1] Majinda, R.R.T., Abegaz, B.M., Bezabih, M., et al. (2001) Resent Resultants from Natural Product Research at the University of Botswana. Pure and Applied Chemistry, 73, 1197-1208. https://doi.org/10.1351/pac200173071197

[2] Mau, J.-L., Huang, P.-N., Huang, S.-J. and Chen, C-C. (2004) Antioxydant Properties of Methanolic Extracts from Two Kinds of Antrodia camphorata Mycelia. Food Chemistry, 86, 25-31. https://doi.org/10.1016/j.foodchem.2003.08.025

[3] Attiyet, A. (1995) Plantes médicinales et aromatiques dans le monde Arabe. Institution arabe pour les études et publication, Beyrouth, $296 \mathrm{p}$.

[4] Farnsworth, N.R., Akerele, O., Bingel, A.S., Soejarto, D.D., et al. (1986) Places des plantes médicinales dans la thérapeutique. Bulletin de lorganisation mondiale de la santé, 64, 159-164.

[5] Scherrer, A.M., Mott, I.R. and Weckerle, C.S. (2005) Traditional Plant Use in the Areas of Monte Vesole and Ascea, Cilento National Park (Campania, Southern Italy). Journal of Ethnopharmacology, 97, 129-143. https://doi.org/10.1016/j.jep.2004.11.002 
[6] Haut Commissariat au Plan (2014) Recensement de la Population et de l'Habitat 2004.

[7] Fennane, M., Ibn Tattou, M., Mathez, J., Ouyahya, A. and El Oualidi, J. (1999) Flore pratique du Maroc. Vol. 1, Trav. Inst. Sci. Rabat, sér. Bot. 36, 558 p.

[8] Fennane, M. and Ibn Tattou, M. (2005) Flore vasculaire du Maroc: Inventaire et Chorologie. Vol. 1, Trav. Inst. Sci., Rabat, sér. Bot. 37, 483 p.

[9] Bellakhdar, J. (1997) La pharmacopée marocaine traditionnelle. Médecine arabe ancienne et savoirs populaires. Editions Le Fennec, Casablanca/Ibis Press, Paris, 764 p.

[10] Kahouadji, A. (1986) Recherches floristiques sur le massif montagneux des Béni Snassène (Maroc oriental). Thèse, Languedoc, 235.

[11] Mehdioui, R. and Kahouadji, A. (2007) Etude ethnobotanique auprès de la population riveraine de la forêt d'Amsittène: Cas de la Commune d'Imi n'Tlit (Province d'Essaouira). Section Sciences de la Vie, Bulletin de P Institut Scientifique, 29, 11-20.

[12] Hseini, S. and Kahouadji, A. (2007) Etude ethnobotanique de la flore médicinale dans la région de Rabat (Maroc occidental). Lazaroa, 28, 79-93.

[13] Salhi, S., Fadli, M., Zidane, L., et al. (2010) Etudes floristique et ethnobotanique des plantes médicinales de la ville de Kénitra (Maroc). Lazaroa, 31, 133-146.

https://doi.org/10.5209/rev_LAZA.2010.v31.9 


\section{Annex}

Table A1. Catalog of the main medicinal plants used by the population of the province of Sidi Slimane.

\begin{tabular}{|c|c|c|c|}
\hline Family & Scientific name & Current name & Vernacular name \\
\hline \multirow{7}{*}{ Apiaceae (7) } & Apium graveolens & Celery & Krafas \\
\hline & Ammi visnaga L. Lam. & Khella & Bachnikha \\
\hline & Coriandrum sativum & Coriander & Kasbour \\
\hline & Cuminum cyminum & Cumin & Kamoun \\
\hline & Foeniculum vulgare & Wild fennel & Besbass \\
\hline & Petroselinum crispum & Parsley & Maâdnous \\
\hline & Pimpinella anisum & Green anise & Habbat hlawa \\
\hline Apocynaceae & Nerium oleander & Pink laurel & Defla \\
\hline \multirow{3}{*}{ Asteraceae (3) } & Artemisia absinthium & Absinthe & Chiba \\
\hline & Chamaemelum nobile & Chamomile & Babounj \\
\hline & Cnicus benedictus & Blessed thistle & Ddad \\
\hline Berberidaceae & Berberis & Barberry & Barztam \\
\hline Cactaceae & Opuntia ficus-indica & Prickly pear & Handia \\
\hline Capparaceae & Capparis spinosa $\mathrm{L}$. & Caper & Kabbar \\
\hline Chenopodiacea & Chenopodium ambrosioides L. & Anserine & Mkhinza \\
\hline Cucurbitaceae & Citrillus colocynthis & Coloquinte & EL Handhel \\
\hline Euphorbiaceae & Ricinus communis $\mathrm{L}$. & Ricin & Kharwaâ \\
\hline \multirow{2}{*}{ Fabaceae (2) } & Trigonella foenum-graecum & Fenugreec & L-Halba \\
\hline & Ceratonia celiqua & Carob tree & EL-Kharroub \\
\hline \multirow{11}{*}{ Lamiaceae (11) } & Marrubium vulgare & White Marube & Marriwt \\
\hline & Thymus & Thyme & Zîitra \\
\hline & Origanum majorana & Marjoram & Merdedouch \\
\hline & Ocimum basilicum $\mathrm{L}$. & Basil & Hbak \\
\hline & Origanum vulgare & Oregano & Zaâtar \\
\hline & Mentha piperita & Wild mint & Naânaa \\
\hline & Romarinus officinalis & Rosemary & Azir \\
\hline & Salvia officinalis & Sage & Salmia \\
\hline & Lavandula officinalis & Lavender & Khzama \\
\hline & Melissa officinalis & melissa & Hbak tranj \\
\hline & Mentha pulegium L. & Pennyroyal mint & Fliyou \\
\hline Lauraceae & Laurus nobilis $\mathrm{L}$. & Laurel noble & Assa sidna moussa \\
\hline \multirow{2}{*}{ Liliaceae (2) } & Alium cepa & Onion & Bessla \\
\hline & Alium sativum & Garlic & Touma \\
\hline Lythraceae & Lawsowia inermis & Henna & Henna \\
\hline Malvaceae & Malva sylvestris & Great purple & Bakkoula \\
\hline \multirow{2}{*}{ Myrtaceae (2) } & Eucalyptus globulus & Eucalyptus & Kalitous \\
\hline & Myrtus communis & Myrtle & Rayhane \\
\hline Oleaceae & Olea enropaea L. & Olivier & Zitoun \\
\hline Polygonaceae & Acetosa rumex & Sorrel & Hommida \\
\hline Renonculacées & Nigella sativa & Nigella & Sanouj \\
\hline Thymelaeaceae & Daphnégarou & Garou & Lezzaz \\
\hline Urticaceae & Urtica & Nettle & Hrriga \\
\hline Vervenaceae & Vervena officinalis & Verbena & Lwiza \\
\hline \multirow{2}{*}{ Zygophyllaceae (2) } & Peganum harmala & Harmal & L-Harmel \\
\hline & Curcuma xanthorrhiza Roxb. & Turmeric & Kharkoum \\
\hline Zingiberaceae & Zingember officinale & Ginger & Skinjbir \\
\hline
\end{tabular}

